\title{
Complexity and Controversies over the Cytokine Profiles of T Helper Cell Subpopulations in Tuberculosis
}

\author{
Marcos Vinicius da Silva, ${ }^{1}$ Monique Gomes Salles Tiburcio, ${ }^{1}$ \\ Juliana Reis Machado, ${ }^{1,2}$ Djalma Alexandre Alves Silva, ${ }^{1}$ \\ Denise Bertulucci Rocha Rodrigues, ${ }^{1,3,4}$ Virmondes Rodrigues, ${ }^{1}$ \\ and Carlo Jose Freire Oliveira ${ }^{1}$ \\ ${ }^{1}$ Laboratory of Immunology, Federal University of Triangulo Mineiro, 38025-180 Uberaba, MG, Brazil \\ ${ }^{2}$ Department of Pathology, Institute of Tropical Pathology and Public Health, Federal University of Goias, \\ 74605-050 Goiania, GO, Brazil \\ ${ }^{3}$ Cefores, Federal University of Triangulo Mineiro, 38015-050 Uberaba, MG, Brazil \\ ${ }^{4}$ Laboratory of Biopathology and Molecular Biology, University of Uberaba, 38055-500 Uberaba, MG, Brazil
}

Correspondence should be addressed to Carlo Jose Freire Oliveira; carlo@icbn.uftm.edu.br

Received 19 November 2014; Accepted 3 February 2015

Academic Editor: Muhammad Atif Zahoor

Copyright (C) 2015 Marcos Vinicius da Silva et al. This is an open access article distributed under the Creative Commons Attribution License, which permits unrestricted use, distribution, and reproduction in any medium, provided the original work is properly cited.

\begin{abstract}
Tuberculosis (TB) is a contagious infectious disease caused by the TB-causing bacillus Mycobacterium tuberculosis and is considered a public health problem with enormous social impact. Disease progression is determined mainly by the balance between the microorganism and the host defense systems. Although the immune system controls the infection, this control does not necessarily lead to sterilization. Over recent decades, the patterns of CD4+ T cell responses have been studied with a goal of complete understanding of the immunological mechanisms involved in the maintenance of latent or active tuberculosis infection and of the clinical cure after treatment. Conflicting results have been suggested over the years, particularly in studies comparing experimental models and human disease. In recent years, in addition to Th1, Th2, and Th17 profiles, new standards of cellular immune responses, such as Th9, Th22, and IFN- $\gamma$-IL-10 double-producing Th cells, discussed here, have also been described. Additionally, many new roles and cellular sources have been described for IL-10, demonstrating a critical role for this cytokine as regulatory, rather than merely pathogenic cytokine, involved in the establishment of chronic latent infection, in the clinical cure after treatment and in keeping antibacillary effector mechanisms active to prevent immune-mediated damage.
\end{abstract}

\section{Introduction}

Tuberculosis (TB) is a contagious infectious disease caused by the TB-causing bacillus Mycobacterium tuberculosis and is considered a public health problem with enormous social impact. Approximately 8.6 million new TB cases and 1.6 million deaths are recorded annually; therefore, this illness is a major cause of death worldwide [1]. Transmission of $M$. tuberculosis occurs by inhalation of droplets containing these bacilli that are eliminated in the sputum of an individual with active disease. In most cases, approximately 90-95\%, M. tuberculosis infection is clinically asymptomatic and not transmitted, a state referred to as latent tuberculosis. It is estimated that one-third of the world population is infected with $M$. tuberculosis, but only 5-10\% will develop active disease at some point in their lives $[1,2]$.

Disease progression is determined mainly by the balance between the microorganism and host defense systems and major changes in the immune status of the individual potentiate $\mathrm{TB}$ activation or reactivation [3]. Although the immune system controls the infection, this control does not necessarily lead to sterilization. Once $M$. tuberculosis can be found in vacuoles of macrophages, the protective immune response against mycobacteria is dependent on 
the interaction between these host cells and CD4+ T cells. Depletion of CD4 or MHC class II molecules in mice impairs control of bacterial growth, and animals succumb to the disease $[4,5]$. Similarly, HIV patients with reduced CD4+ T cells are highly susceptible to tuberculosis [6].

Over recent decades, the patterns of $\mathrm{CD} 4+\mathrm{T}$ cell responses have been studied, with the goal of complete understanding of the immunological mechanisms involved in the maintenance of latent or active tuberculosis infection and of the clinical cure after treatment. Conflicting results have been suggested over the years, particularly in studies comparing experimental models and human disease. In recent years, in addition to Th1, Th2, and Th17 profiles, new standards of cellular immune response, such as Th9 and Th22, have also been described (Table 1). Similarly, several studies have pointed IL-10 as a crucial regulator to determine the quality and intensity of the immune response, demonstrating a major role in the establishment of latent infection, to prevent immune-mediated damage and establishment of clinical cure after treatment keeping the antibacillary effector mechanisms.

\section{T Helper Cells and Immune Response in Tuberculosis}

T cell-mediated immune response begins after dissemination of $M$. tuberculosis to the lymph nodes $[66,67]$. After activation and expansion of antigen-specific $\mathrm{T}$ cells, they then migrate to the infected lungs where they are found, together with other leukocytes, as part of granulomas. Several distinct types of T helper cells (such as Th1, Th2, Th17, and regulatory $\mathrm{T}$ cells) are present at the site of infection (Table 1); however, the Thl subset is classically associated with impaired growth and dispersion of Mycobacterium tuberculosis [68]. Because each pattern of immune response culminates in different effector mechanisms, it is essential to understand the role of each one in response to $M$. tuberculosis.

2.1. Th1. IFN- $\gamma$, the main cytokine of the Th1 profile, enhances macrophage microbicidal mechanisms because it activates signaling pathways that include the iNOS pathway $[39,40]$ and induces the process of acidification and maturation of phagosomes and autophagy [41]. The main source of the IFN- $\gamma$ that is responsible for the control of M. tuberculosis is CD4+ T cells [69]. Additional roles in the production of that cytokine are attributed to CD8+ T cells, natural killer cells, $\gamma \delta \mathrm{T}$ cells, and CD-1 restricted T cells; however, none of them can compensate for the absence of CD4+ T cells [68]. The importance of IFN- $\gamma$ in response to $M$. tuberculosis has been widely investigated in experimental models and in humans. Knockout mice for IL-12 [7], IFN$\gamma[8,9]$, or T-bet [10] are highly susceptible to TB. It was also demonstrated that a reduction in IFN- $\gamma$ may lead to an increased influx of neutrophils and extensive tissue damage resulting in tuberculosis in animal models [38]. Individuals with mutations in the IL-12/IFN- $\gamma$ axis develop disseminated infection caused by BCG or nontuberculous species of mycobacteria [11]. Furthermore, results from our group and other studies have also demonstrated that peripheral blood mononuclear cells (PBMCs) from patients with active disease secrete lower levels of IFN- $\gamma$ in vitro, both in unstimulated cultures or after stimulation with mitogens or mycobacterial antigens $[13,33,58,60,70-74]$. A recovery of the ability to produce IFN- $\gamma$ after specific antituberculosis therapy was also demonstrated, but this production was found at low levels when compared with patients with latent tuberculosis $[74,75]$.

Despite the important role of IFN- $\gamma$ in the fight against M. tuberculosis, some studies have shown that production of this cytokine is not sufficient to prevent active disease. Most people who develop active TB are able to activate IFN-producing $\mathrm{T}$ cells that are specific for M. tuberculosis at the site of infection [34-37]. It has been shown that patients whose $\mathrm{T}$ cells produce higher amounts of IFN- $\gamma$ are more likely to progress to active disease than patients with weaker responses [76]. One possible explanation for the contradictory results regarding the production of IFN$\gamma$ at the site of infection and in peripheral blood is that the PBMCs of patients with active disease are more susceptible to apoptosis than healthy controls [77]. Moreover, in patients with active disease, $\mathrm{T}$ cells specific for mycobacterial antigens have been shown to be recruited and retained in lung tissues. In fact, several authors have shown that there is sometimes a positive relationship between circulating T-cell clones and those retained in the site of infection, especially in patients with active disease [78-80].

The notion that IFN- $\gamma$ is necessary but not sufficient for bacterial control after infection is also supported by several studies in knockout mice for TNF- $\alpha$, granulocytes, GM-CSF, IL-1, and IL-6, as they also die rapidly after $M$. tuberculosis infection. In other words, these results suggest that additional pathways are essential for immunity against M. tuberculosis [81]. Several experimental models have also linked the production of TNF- $\alpha$ with the maintenance of granuloma integrity, and changes in their levels have been correlated with disease susceptibility both in experimental models and in human patients [33, 42-44]. In fact, TNF- $\alpha$ acts synergistically with IFN- $\gamma$ to stimulate the production of NO by macrophages and influences the expression of chemokines, such as CCL5, CCL9, CXCL10, and CCL2, which induce migration to and maintenance of immune cells in the infection site [82]. Blocking TNF- $\alpha$, for example, in the treatment of rheumatoid arthritis, leads to a loss of granuloma structure and reactivation of the disease [45-48]. Conversely, M. tuberculosis-specific stimulation of IFN- $\gamma$ (but not TNF- $\alpha$ ) and IFN $-\gamma$ R signaling are significantly depressed in active TB, which correlates with TB disease severity and activity. Thus, the depression of both TNF- $\alpha$ and IFN- $\gamma$ production and IFN- $\gamma \mathrm{R}$ signaling may synergize to contribute to defective host control in active TB [74].

2.2. Th2. The role of Th2 cytokines, classical antagonists of the Thl profile, has not been fully elucidated in experimental models or in patients with tuberculosis. Although these cytokines may be involved in mechanisms of evasion of $M$. tuberculosis from the immune system, their direct participation in disease reactivation is even more controversial [83]. 
TABLE 1: T helper cell (Th) subtypes and Th-related soluble mediators in human and experimental tuberculosis.

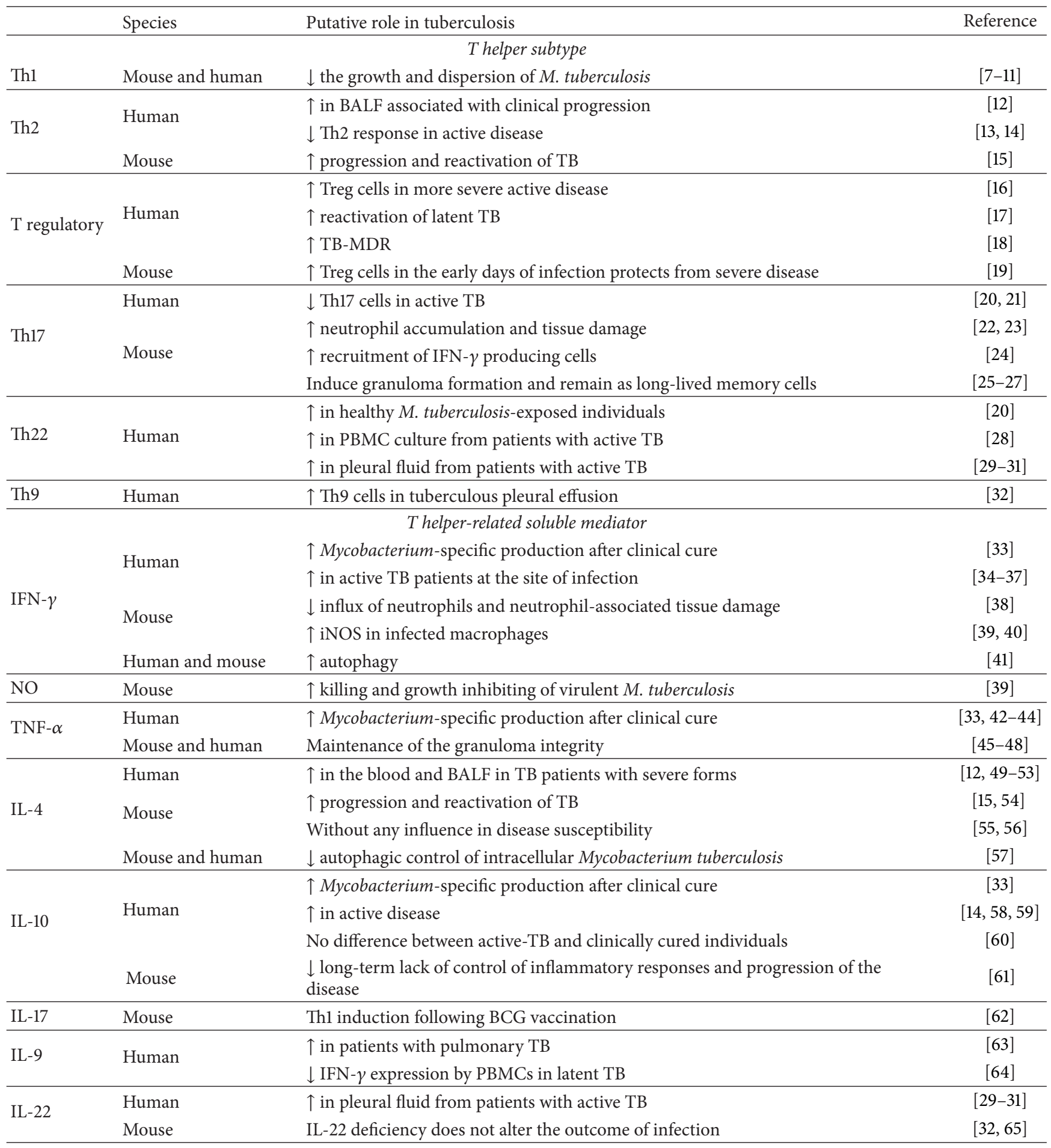

In experimental models, some studies have shown an association of increased IL-4 with progression of tuberculosis and reactivation of the disease $[15,54]$, but other authors have shown that the absence of this cytokine does not influence susceptibility to the disease $[55,56]$.

In human tuberculosis controversial results are also observed with respect to induction of the Th2 subset of
CD4+ T cells. Some authors have demonstrated increased levels of IL-4 in the blood [49-52] and in bronchoalveolar lavage fluid (BALF) in patients with TB, especially those with the more severe forms [53]. Ashenafi et al. have recently demonstrated an association between high levels of IL-4 and CCL4 in BALF, increased expression of SOCS3, and clinical progression of the disease. Furthermore, a positive 
correlation was found between IL- 4 and CCL4 levels and mycobacteria-specific IgG titers in BALF and plasma samples [12]. In other studies, it was observed that the decrease in Th1 response in patients with active disease is not accompanied by an increase in the Th2 pattern $[13,14]$. When examining the kinetics of Th1 and Th2 cytokine production in patients with active disease, the secretion of both types of cytokines has been shown by using PBMCs from active TB patients [84]. Also, Marchant and colleagues demonstrated that, prior to therapeutic intervention, there is a predominance of "Th0" cells because concomitant expression of IFN- $\gamma$ and IL-4 was found; however, with treatment progression, there was a decrease in clones producing IL-4. In contrast, patients with treatment-resistant tuberculosis showed an increase in "Th0" cells because there was persistent production of IL-4 regardless of the presence or absence of treatment [84].

The participation of Th2 cytokines in susceptibility to tuberculosis was reinforced by the description of the importance of autophagy in immunity against $M$. tuberculosis $[41,85]$. It is known that IL-4 and IL-13 cytokines act as inhibitors of the autophagic process $[57,86]$, impairing antigen presentation, $\mathrm{T}$ cell clonal expansion, and consequently the organization of granulomas in tuberculosis [85-87]. However, it remains unclear whether the production of Th2 cytokines is a primary cause of reactivation of tuberculosis or just a consequence of progression of the active infection $[83,88]$.

2.3. T Regulatory. In many chronic infections, including $\mathrm{TB}$, immune-mediated tissue injury can lead to greater damage to the host when compared with the presence of the pathogen itself. Thus, it is important that mechanisms are activated to counterregulate proinflammatory immune responses and prevent the harmful effects of excessive inflammation [81]. Regulatory T cells (Foxp3+ CD4+ and CD25+ (Treg)) suppress inflammation and limit immune responses by producing immunosuppressive cytokines, such as IL-10, IL-35, and TGF- $\beta$, and directly interacting with other cells by inhibiting surface molecules [89].

The role of Treg cells in tuberculosis, especially in human disease, still remains controversial. Some studies suggest that the involvement of Treg cells is observed more in individuals with more severe active disease [16], and depletion of these cells results in the production of high levels of IFN- $\gamma[33$, 90-93]. Previous results also suggest an important role for regulatory $\mathrm{T}$ cells in reactivation of latent tuberculosis and development of active tuberculosis by decreasing the production of IFN- $\gamma$, while production of IL-17 continues to induce the accumulation of polymorphonuclear leukocytes at lung sites [17]. Additionally, one study suggests that a concomitant increase in the proportion of CD4+ CD25+ and CD4+ CD25+ Foxp3+ cells are associated with active pulmonary tuberculosis [94], but the depletion of CD4+ CD25+ cells has no effect on bacterial load or lung damage due to infection [95]. A recent study by Chen and colleagues showed that, in experimental tuberculosis, concomitant expansion of regulatory $\mathrm{T}$ cells (Foxp3+ $\mathrm{T}$ cells) and effector $\mathrm{T}$ cells is already occurring in the early days of infection, and this increase is critical for control of the parasite because it protects from severe disease [19]. Despite these results, it is known that the persistent stimulation in multidrug-resistant tuberculosis increases Treg cells and could be a cofactor in clinical cure delay [18].

2.4. Th17. Activation of naive $\mathrm{T}$ cells in the presence of TGF- $\beta$ and IL- 6 directs the differentiation of these cells into Th17 cells through activation of STAT-3. This in turn increases expression of the transcription factor ROR $\gamma t$ and promotes the production of both proinflammatory cytokines IL-17 and IL-22 [96]. The induction of IL-21 mediated by IL6 also strengthens the engagement of the Th17 strain in an autocrine fashion. It is known that TGF- $\beta$ is produced in excess during tuberculosis and is expressed at sites of active M. tuberculosis infection [97], suggesting their involvement in the differentiation of Th17 cells in addition to its wellknown immunomodulatory role. For tuberculosis, it has been shown that IL-23 is required for the development of Th17 cells because mice deficient in the p19 subunit of IL-23 are unable to maintain sustained expression of IL-17 during the course of infection [98]. In the same study, however, it was suggested that the Th17 response is dispensable for protection against infection.

Wozniak et al. suggest that cross-regulation of Thl and Th17 populations is essential for conferring a significant protective effect against $M$. tuberculosis without excessive damage [25]. In agreement with these findings, another study showed that, during infection with M. tuberculosis, IFN- $\gamma$ inhibits the production of IL-17 by CD4+ T cells, impairing the survival of neutrophils and the accumulation of these cells in infected lungs, which contributes to a reduction in inflammation [38]. Cruz et al. showed that IFN- $\gamma$-deficient mice infected with mycobacteria exhibit intensified accumulation of neutrophils and IL-17-producing T cells in the granulomatous lesions and that these cells did not control the growth of bacteria and yet compromised the integrity of the infected tissue [22]. These data suggest that IFN- $\gamma$ appears to limit the population IL-17-producing cells. The involvement of IL-17 and IL-23 in mediating the immunopathology of TB has also been demonstrated by Cruz et al. [23].

In contrast, some studies have indicated that cells producing IL-17 may confer protection in patients with tuberculosis. Khader et al. demonstrated in an experimental model that IL17 is required to accelerate the recruitment of cells producing IFN- $\gamma$ in the lung, and this effect is a result of increasing concentrations of the chemokines CXCL9, CXCL10, and CXCL11 [24]. Recently, Gopal et al. suggested that an IL-17 mediated response is required for induction of a Th1 response following vaccination with BCG [62]. Other studies have also shown that Th17 cells, in addition to inducing the early events of granuloma formation [26] and remaining as long-lived memory cells $[25,26,99]$, can also mediate mechanisms of protection independent of IFN- $\gamma[25,27]$. In humans, some studies have noted that there is a deficient Th17 response in patients with active $\mathrm{TB}$, especially when compared with latent $\mathrm{TB}$, a finding that does not seem to be related to a large recruitment of these cells to the lung environment $[20,21]$. 
2.5. Th22. IL-22 is a member of the IL-10 family of cytokines, which are mainly produced by Th17 cells. However, recently, a subpopulation of human T cells producing IL-22 has been described as a separate helper $\mathrm{T}$ cell line known as Th22. The differentiation of these cells occurs from naïve precursors and is dependent on IL- 6 and TNF- $\alpha$ via activation of the transcription factor aryl-hydrocarbon receptor (AhR) [100]. It appears that IL-22 is important for inflammatory responses in the skin and mucosal surfaces because it has been reported in a number of human diseases, including inflammatory bowel disease, psoriasis, and rheumatoid arthritis [101]. Despite reports that IL-22 deficiency or neutralization does not alter the outcome of $M$. tuberculosis infection in mice [32, 65], studies in patients with tuberculosis have shown the presence of IL-22-producing CD4+ T cells: Scriba et al. demonstrated that a substantial proportion of mycobacteria-specific Th cells from healthy $M$. tuberculosis-exposed individuals produce IL-22 and are distinct from Th17 and Th1 cells, implicating IL22 as an important cytokine axis in human antimycobacterial immunity [20]. Similarly, Qiu et al. demonstrated that there is an intense production of IL-22 and IFN- $\gamma$ by distinct subsets of CD4+ T cells in cultures of PBMCs from patients with active $\mathrm{TB}$, and these populations were reciprocally regulated after blocking such cytokines in culture with monoclonal antibodies [28].

Patients with tuberculous pleural effusion have an increased concentration of IL-22 and Th22 cells in pleural fluid samples that exceed the corresponding blood levels in the same patients, suggesting that this cytokine may be involved in pathogenesis of the disease [29-31]. Most Th22 cells in the pleural effusion exhibited a phenotype of effector memory cells, expressing high levels of CD45RO and low levels of CD45RA and CD62L. In addition, it was shown that IL-1 $\beta$, IL- 6 , and TNF- $\alpha$ can promote the differentiation of Th22 cells from naive CD4+ T cells and that combinations of these cytokines promote differentiation at more pronounced levels [63].

2.6. Th9. IL-9 has long been considered a Th2 cytokine due to its participation in processes of allergic inflammation. However, recent studies have revealed that this cytokine has other important functions and distinct subpopulations of CD4+ T cells, called Th9, are able to produce them. Th9 cells are characterized by production of IL- 9 and IL-10 and develop from a naïve $\mathrm{CD} 4+$ precursor in the presence of TGF$\beta$ and IL-4 [102]. Some studies show that Th9 cells can trigger inflammation and contribute to the development of allergic diseases [64]; however, the roles of these cells in infectious diseases, including tuberculosis, are not well established.

Recently, Ye and collaborators demonstrated the presence of Th9 cells in patients with tuberculous pleural effusion. The differentiation of Th9 cells from CD4+ cells that were isolated from the pleural effusion or blood of these patients was dependent on TGF- $\beta$, and the production of IL-9 in the cultures was amplified by the addition of IL-4, IL-1 $\beta$, and IL-6. It was also suggested in the same work that IL-9 may be, along with TGF- $\beta$, promoting the differentiation of Th17 cells because a positive correlation was observed between the number of Th9 and Th17 cells in the pleural effusion [63].
Although the participation of Th9 cells in tuberculosis has not been reported in other studies, production of the cytokine IL-9 has been widely demonstrated in some studies. One example is that patients with pulmonary TB had significantly higher levels of IL-6 and IL-9 compared to healthy controls $[103,104]$. Hur et al. found that IL-9 production, together with IL-5, IL-13, and IL-17 in response to antigens ESAT-6/CFP10 , can potentially differentiate between latent $M$. tuberculosis infection and infections with environmental mycobacteria, such as M. avium and M. kansasii [105]. Moreover, in patients with latent TB, the addition of exogenous IL-9 reduced the expression of IFN- $\gamma$ by PBMCs in vitro, and neutralization of IL-9 restored IFN- $\gamma$ production, suggesting that IL-9 may contribute to the development of TB by promoting an impaired Thl response [106].

\section{IL-10 and Tuberculosis-A Delicate Balance between Bacillary Persistence and Reducing Damage}

Several studies have indicated that the recurrence of tuberculosis is associated more with reemergence of a previous infection than with a new infection, reinforcing the concept that antituberculosis immunity that is generated after treatment culminates in clinical recovery but without resulting in a sterilizing cure. This aspect seems crucial because immune responses mediated by both effector (especially Th1 and Th17) and regulatory ( $\mathrm{T}$ regulatory cells and IL-10) mechanisms are required to allow the patient to fight against the bacilli without suffering extensive lung damage or death. Indeed, because the activity of unrestrained TNF and IFN- $\gamma$ can be detrimental to the host under conditions of infection or microbial colonization, including during $M$. tuberculosis infection, various mechanisms are in place to prevent immunopathology, including those mediated by Foxp3+ regulatory T cells $[16,90,91,93]$ and IL-10 $[14,58-60,74]$. Contrary to what was initially believed, the ability to produce IL-10 has been shown not only in Th2 and Treg [107, 108] cells but also in Th1, Th9, Th17, and CD8+ T cells, especially those that are long-lived [107-119], and the occurrence of these multifunctional populations in the context of IL-10 still needs to be correctly determined in human tuberculosis.

Previous results from our group [33] note an interesting time-dependent effect in the establishment of protective immunity after antimicrobial therapy against $M$. tuberculosis. We demonstrated that the establishment of a Thl response, characterized by increased production of IFN- $\gamma$ and TNF$\alpha$, occurs later, as evidenced in patients who had been cured for over 12 months, and is accompanied by increased IL-10 production [33]. This slow development of a Th1 response in human tuberculosis differs from that observed in cutaneous leishmaniasis, a protozoan infection in which the Th1 response is also associated with cure and the Th1 response is induced immediately after treatment [120]. Consequently, our results indicate that although the process of clinical cure progresses with potentiation of Thl cytokine production (IFN- $\gamma$ and TNF- $\alpha$ ), the production of higher levels of IL-10 is important for regulating the production of these proinflammatory cytokines [110]. The balance between these 
regulators and TNF/IFN- $\gamma$ may determine if the immune system can eradicate $M$. tuberculosis with minimum associated damage.

There is a growing body of evidence suggesting that the relationship between IL-10 and Th1 cytokines is not as antagonistic as originally believed, and infectious diseases appear to act in a complementary form [121]. Studies show that, for some infectious diseases, an increase in IL10 potentially acts to decrease the deleterious effects of inflammation derived from Thl cytokines without affecting the clearance of infectious agents [121-124], such as Listeria monocytogenes, Trypanosoma cruzi, and influenza virus [125127]. Similarly, the protective response to Toxoplasma gondii is associated with IFN- $\gamma$, although in the absence of IL10 , infected animals may die due to extensive early tissue damage $[128,129]$. In vitro approaches suggest that the sources of IL-10 in these infections are Th1 cells and these IL-10producing Th1 cells still maintain their ability to activate macrophages [121]. CD4+ CD25+ Treg cells are also related to this function, especially in Leishmania major infection [90, 117,118 ]. Also, during L. major infection, although the absence of IL-10 enhanced pathogen clearance, mice displayed a loss of immunity to reinfection, suggesting that IL-10 does limit pathogen clearance but has a key role in the maintenance of effector memory populations via a mechanism that remains unknown [130]. Knockout mice for IL-10 that were infected with $M$. tuberculosis did not show increased IFN- $\gamma$ production [131], although they did show long-term lack of control of inflammatory responses and progression of the disease [61]. Additionally, IL-10 can also enhance inflammatory mediators, especially in an environment that is rich in IFN- $\gamma$ [119].

With regard to the dynamics of IL-10 production in tuberculosis active disease and after clinical cure, the results are conflicting. Some studies indicate that there are higher levels of IL-10 in active tuberculosis [14, 58, 59], but Sahiratmadja and colleagues showed that this increase happens only after clinical cure [74]. Still, Zhang and colleagues showed no change in the levels of IL-10 among individuals with active disease and those who had been treated [60]. Recently, Siawaya and colleagues found that, during antituberculosis therapy, there were no major changes in the levels of IL-10; however, patients who had lower levels of this cytokine in the earlier stages had negative cultures for $M$. tuberculosis, indicating better bacterial clearance in these individuals [132]. Pereira and colleagues found that, in addition to an enhancement in the production of TNF$\alpha$, patients with systemic manifestations of tuberculosis have increased production of IL-10 [73]. These data suggest that IL-10 can have deleterious effects on the patient during active disease. Gerosa and colleagues have previously shown that there is concomitant production of IFN- $\gamma$ and IL-10 by Th1 lymphocytes as well as by memory $\mathrm{T}$ cells in bronchoalveolar lavage fluid obtained from patients with active tuberculosis [133]. If the IL-10 somehow acts as a weapon used by the bacilli to interfere with proper macrophage activation during active infection, participation in controlling exacerbation of the immune response seems to be of vital importance to the infected individual [134].
In recent years, special attention has been given to socalled double-cytokine-producing effector $\mathrm{T}$ cells and their role in mediating the immune response in several infectious diseases, especially protagonists of the Th1 response, which is the case with toxoplasmosis, malaria, and leishmaniasis [33, 121, 135-137]. Initially, Th2 cells were the main populations of $\mathrm{T}$ cells that produced IL-10 in a sustained manner [138140]. Later, several groups reported an associated production of IFN- $\gamma$ and IL-10 [121, 141-144] and subsequently IL-17 and IL-10 [124]. These studies have not yet been able to determine if these populations are stable or are only transitory stages, where the production of IL-10 occurs only transiently and returns to its initial profile [145].

Experimental models suggest that the generation of IL10 -producing Th1 cells is due to chronic or repeated antigenic stimulation [146-149] because newly differentiated Thl cells are apparently unable to secrete IL-10 due to the inaccessibility of the IL-10 gene promoter [139]. In fact, as mentioned earlier, several studies have indicated that the expression of IL-10 in cells that were initially committed to rigid profiles, such as Th1, Th2 or Th17, may reflect a mechanism of self-control after repeated antigenic stimulation where cell survival should be extended. Previous work in experimental models demonstrated that external factors, such as antigenic load and increased presence of IL-12, may direct Th1 cells to expression of IL-10, which returns to baseline upon removal of these stimuli $[23,150]$. Moreover, this production is dependent on both the induction of STAT-1, which is classically associated with Th1 and IFN- $\gamma$ production, and STAT-3, particularly via the IL-27-IL-27R axis [146, 147]. In Th17 cells, production is dependent on STAT-3 and IL27-IL27R axis after induction by IL-6 and IL-21 [148-150]. Studies indicate that the IL-10/STAT-3 axis is essential for the development and function of CD8+ memory $\mathrm{T}$ cells [154-156] and expansion of these cells with IL-10 production capacity occurs during chronic infection with $M$. tuberculosis [157].

In addition to the aforementioned signaling pathways, the signaling receptor Notch has been shown to be essential for production of IL-10 by CD4+ T cells, as well as the IFN$\gamma+$ and IL-10+ double-producing $\mathrm{T}$ cells $[158,159]$. These receptors have also been associated with IFN- $\gamma$, especially via Notch1 and Notch2 during Leishmania major infection [160]. Indeed, stimulation of the Notch pathway via DLL-4, a prominent Notch receptor ligand, is described as guiding STAT-3, and consequently, IL-10 [156] and Notch signaling pathway has also been associated with increased survival of $\mathrm{T}$ cells [161], data that together could strengthen understanding of the occurrence of these double-producing cells in chronic pathological processes. Current results from our group indicate that a higher percentage of CD4+ cells express Notch1 in patients who are clinically cured of tuberculosis, a condition that is characterized by increased IFN- $\gamma$ and IL- 10 .

Furthermore, FoxP3- CD4+ memory cells, especially those that express CCR6, are induced by IL-10 and secrete the same cytokines with the purpose of self-regulation [162]. We should also consider that the decrease in IFN- $\gamma$ and TNF$\alpha$ in the supernatants of these cell strains can only be the result of apoptosis of IL-10-producing Th1 cells after their 
suppression. Several studies have also indicated that antiapoptotic functions of IL-10 are important because blocking this cytokine makes non-Hodgkin's lymphoma cells more susceptible to apoptosis [163] and increases cell apoptosis in the retina [164]. In addition, IL-10 prevents T-cell mediated apoptosis by parainfluenza virus type 3 (PIV3) [165] and EBV [166] and inhibits apoptosis of cardiomyocytes, monocytes, and macrophages $[167,168]$, especially via the induction of STAT-3 [169].

Over the years, several studies have examined the ability of DNA vaccines based on mycobacteria HSPs, particularly HSPs from M. tuberculosis and M. leprae, to provide protection against pulmonary tuberculosis. Interestingly, although the results indicate their ability to induce protective immunity against $M$. tuberculosis by enhancing effector populations of CD4 and CD8+ T cells and increasing IFN- $\gamma$ [170-175], they also induce regulatory T cells and IL-10 for potential inhibition of autoimmune manifestations [147-149, 176-178], demonstrating a practical situation of success in controlling infection with M. tuberculosis with effector/regulator concurrent mechanisms.

In the context of human infection with M. tuberculosis, we understand that the influence of IL-10 on inhibiting apoptosis of $\mathrm{T}$ cells is crucial for maintaining the repertoire of cells that are responsible for bacillary control, maintenance of clinical latency, long preservation of lymphocyte life and memory, and therefore the ability to produce those cytokines that are related to protection and preservation of granulomas.

\section{Conclusions}

Based on careful surveys of the literature and published works from our group, we have come to the following conclusions:

(i) The balance between resistance and susceptibility to infection with $M$. tuberculosis is a very complex mechanism and presents several controversies over the cytokine profiles of $\mathrm{T}$ helper cell subpopulations.

(ii) IL-10 appears to have an important role in shaping the repertoire of $\mathrm{T}$ helper lymphocytes, irrespective of other cytokines that define their subpopulations.

(iii) Chronic infection in the presence of IL-10 appears to exert a regulatory role and minimize tissue damage, but without compromising the immune mechanisms involved in the control of $M$. tuberculosis and other related microorganisms.

\section{Conflict of Interests}

The authors declare that they have no conflict of interests.

\section{Acknowledgments}

This work was supported, in whole or in part, by the Coordenação de Aperfeiçoamento de Pessoal de Nível Superior (CAPES), Programa Nacional de Incentivo à Pesquisa em Parasitologia Básica (Edital 32/2010), PNPD-CAPES, Fundação de Amparo à Pesquisa do Estado de Minas Gerais
(FAPEMIG, Grants 20/2012, 13-2014, and CBB-APQ-0134612), and Conselho Nacional de Desenvolvimento Científico e Tecnológico (CNPq).

\section{References}

[1] WHO, Global Tuberculosis Report 2013, 2013.

[2] H. Hartman-Adams, K. Clark, and G. Juckett, "Update on latent tuberculosis infection," American Family Physician, vol. 89, no. 11, pp. 889-896, 2014.

[3] J. L. Flynn and J. Chan, "Immunology of tuberculosis," Annual Review of Immunology, vol. 19, pp. 93-129, 2001.

[4] A. M. Caruso, N. Serbina, E. Klein, K. Triebold, B. R. Bloom, and J. L. Flynn, "Mice deficient in CD4 T cells have only transiently diminished levels of IFN- $\gamma$, yet succumb to tuberculosis," Journal of Immunology, vol. 162, no. 9, pp. 5407-5416, 1999.

[5] T. Mogues, M. E. Goodrich, L. Ryan, R. LaCourse, and R. J. North, "The relative importance of $\mathrm{T}$ cell subsets in immunity and immunopathology of airborne Mycobacterium tuberculosis infection in mice," The Journal of Experimental Medicine, vol. 193, no. 3, pp. 271-280, 2001.

[6] C. Geldmacher, A. Zumla, and M. Hoelscher, "Interaction between HIV and Mycobacterium tuberculosis: HIV-1-induced CD4 T-cell depletion and the development of active tuberculosis," Current Opinion in HIV and AIDS, vol. 7, no. 3, pp. 268-275, 2012.

[7] A. M. Cooper, J. Magram, J. Ferrante, and I. M. Orme, "Interleukin 12 (IL-12) is crucial to the development of protective immunity in mice intravenously infected with Mycobacterium tuberculosis," The Journal of Experimental Medicine, vol. 186, no. 1, pp. 39-45, 1997.

[8] J. L. Flynn, J. Chan, K. J. Triebold, D. K. Dalton, T. A. Stewart, and B. R. Bloom, "An essential role for interferon $\gamma$ in resistance to Mycobacterium tuberculosis infection," Journal of Experimental Medicine, vol. 178, no. 6, pp. 2249-2254, 1993.

[9] A. M. Cooper, D. K. Dalton, T. A. Stewart, J. P. Griffin, D. G. Russell, and I. M. Orme, "Disseminated tuberculosis in interferon $\gamma$ gene-disrupted mice," The Journal of Experimental Medicine, vol. 178, no. 6, pp. 2243-2247, 1993.

[10] B. M. Sullivan, O. Jobe, V. Lazarevic et al., "Increased susceptibility of mice lacking T-bet to infection with Mycobacterium tuberculosis correlates with increased IL-10 and decreased IFNgamma production," Journal of Immunology, vol. 175, no. 7, pp. 4593-4602, 2005.

[11] J.-L. Casanova and L. Abel, "Genetic dissection of immunity to mycobacteria: the human model," Annual Review of Immunology, vol. 20, pp. 581-620, 2002.

[12] S. Ashenafi, G. Aderaye, A. Bekele et al., "Progression of clinical tuberculosis is associated with a Th2 immune response signature in combination with elevated levels of SOCS3," Clinical Immunology, vol. 151, no. 2, pp. 84-99, 2014.

[13] Y. Lin, M. Zhang, F. M. Hofman, J. Gong, and P. F. Barnes, "Absence of a prominent Th2 cytokine response in human tuberculosis," Infection and Immunity, vol. 64, no. 4, pp. 13511356, 1996.

[14] S. Winkler, M. Necek, H. Winkler et al., "Increased specific $\mathrm{T}$ cell cytokine responses in patients with active pulmonary tuberculosis from Central Africa," Microbes and Infection, vol. 7, no. 9-10, pp. 1161-1169, 2005.

[15] R. Hernández-Pando, H. Orozcoe, A. Sampieri et al., "Correlation between the kinetics of Th1, Th2 cells and pathology 
in a murine model of experimental pulmonary tuberculosis," Immunology, vol. 89, no. 1, pp. 26-33, 1996.

[16] J. C. Ferraz, F. B. S. Melo, M. F. P. M. Albuquerque, S. M. L. Montenegro, and F. G. C. Abath, "Immune factors and immunoregulation in tuberculosis," Brazilian Journal of Medical and Biological Research, vol. 39, no. 11, pp. 1387-1397, 2006.

[17] N. D. Marin, S. C. París, V. M. Vélez, C. A. Rojas, M. Rojas, and L. F. García, "Regulatory T cell frequency and modulation of IFN-gamma and IL-17 in active and latent tuberculosis," Tuberculosis (Edinb), vol. 90, no. 4, pp. 252-261, 2010.

[18] L. Geffner, N. Yokobori, J. Basile et al., "Patients with multidrugresistant tuberculosis display impaired Th1 responses and enhanced regulatory T-cell levels in response to an outbreak of multidrug-resistant Mycobacterium tuberculosis $\mathrm{M}$ and $\mathrm{Ra}$ strains," Infection and Immunity, vol. 77, no. 11, pp. 5025-5034, 2009.

[19] C. Y. Chen, D. Huang, S. Yao et al., "IL-2 simultaneously expands Foxp $3^{+} \mathrm{T}$ regulatory and $\mathrm{T}$ effector cells and confers resistance to severe tuberculosis (TB): implicative treg-T effector cooperation in immunity to TB," The Journal of Immunology, vol. 188, no. 9, pp. 4278-4288, 2012.

[20] T. J. Scriba, B. Kalsdorf, D.-A. Abrahams et al., "Distinct, specific IL-17- and IL-22-producing $\mathrm{CD}^{4+} \mathrm{T}$ cell subsets contribute to the human anti-mycobacterial immune response," Journal of Immunology, vol. 180, no. 3, pp. 1962-1970, 2008.

[21] X. Chen, M. Zhang, M. Liao et al., "Reduced Th17 response in patients with tuberculosis correlates with IL-6R expression on $\mathrm{CD} 4{ }^{+} \mathrm{T}$ cells," American Journal of Respiratory and Critical Care Medicine, vol. 181, no. 7, pp. 734-742, 2010.

[22] A. Cruz, S. A. Khader, E. Torrado et al., "Cutting edge: IFN$\gamma$ regulates the induction and expansion of IL-17-producing CD4 T cells during mycobacterial infection," The Journal of Immunology, vol. 177, no. 3, pp. 1416-1420, 2006.

[23] A. Cruz, A. G. Fraga, J. J. Fountain et al., "Pathological role of interleukin 17 in mice subjected to repeated BCG vaccination after infection with Mycobacterium tuberculosis," Journal of Experimental Medicine, vol. 207, no. 8, pp. 1609-1616, 2010.

[24] S. A. Khader, G. K. Bell, J. E. Pearl et al., "IL-23 and IL-17 in the establishment of protective pulmonary $\mathrm{CD}^{+} \mathrm{T}$ cell responses after vaccination and during Mycobacterium tuberculosis challenge," Nature Immunology, vol. 8, no. 4, pp. 369-377, 2007.

[25] T. M. Wozniak, B. M. Saunders, A. A. Ryan, and W. J. Britton, "Mycobacterium bovis BCG-specific Th17 cells confer partial protection against Mycobacterium tuberculosis infection in the absence of gamma interferon," Infection and Immunity, vol. 78, no. 10, pp. 4187-4194, 2010.

[26] Y. O. Yoshida, M. Umemura, A. Yahagi et al., "Essential role of IL-17A in the formation of a mycobacterial infection-induced granuloma in the lung," Journal of Immunology, vol. 184, no. 8, pp. 4414-4422, 2010.

[27] A. M. Gallegos, J. W. J. van Heijst, M. Samstein, X. Su, E. G. Pamer, and M. S. Glickman, "A gamma interferon independent mechanism of CD4 T cell mediated control of M. tuberculosis infection in vivo," PLoS Pathogens, vol. 7, no. 5, Article ID e1002052, 2011.

[28] Y. Qiu, Y. Huang, J. Chen, D. Qiao, G. Zeng, and J. Cai, "Depletion of IL-22 during culture enhanced antigen-driven IFN-gamma production by $\mathrm{CD}^{+} \mathrm{T}$ cells from patients with active TB," Immunology Letters, vol. 150, no. 1-2, pp. 48-53, 2013.

[29] K. Matthews, K. A. Wilkinson, B. Kalsdorf et al., "Predominance of interleukin-22 over interleukin-17 at the site of disease in human tuberculosis," Tuberculosis, vol. 91, no. 6, pp. 587-593, 2011.

[30] D. Qiao, B. Y. Yang, L. Li et al., "ESAT-6- and CFP-10specific Th1, Th22 and Th17 cells in tuberculous pleurisy may contribute to the local immune response against Mycobacterium tuberculosis infection," Scandinavian Journal of Immunology, vol. 73, no. 4, pp. 330-337, 2011.

[31] L. Li, D. Qiao, X. Fu, S. Lao, X. Zhang, and C. Wu, "Identification of mycobacterium tuberculosis-specific Th1, Th17 and Th22 cells using the expression of CD40L in tuberculous pleurisy," PLoS ONE, vol. 6, no. 5, Article ID e20165, 2011.

[32] J. Behrends, J.-C. Renauld, S. Ehlers, and C. Hölscher, "IL-22 is mainly produced by IFN $\gamma$-secreting cells but is dispensable for host protection against Mycobacterium tuberculosis infection," PLoS ONE, vol. 8, no. 2, Article ID e57379, 2013.

[33] M. V. da Silva, A. A. Figueiredo, J. R. Machado et al., "T cell activation and proinflammatory cytokine production in clinically cured tuberculosis are time-dependent and accompanied by upregulation of IL-10," PLoS ONE, vol. 8, no. 6, Article ID e65492, 2013.

[34] S. K. Schwander, M. Torres, E. Sada et al., "Enhanced responses to Mycobacterium tuberculosis antigens by human alveolar lymphocytes during active pulmonary tuberculosis," Journal of Infectious Diseases, vol. 178, no. 5, pp. 1434-1445, 1998.

[35] J. Nemeth, H.-M. Winkler, R. H. Zwick et al., "Recruitment of mycobacterium tuberculosis specific $\mathrm{CD}^{4+} \mathrm{T}$ cells to the site of infection for diagnosis of active tuberculosis," Journal of Internal Medicine, vol. 265, no. 1, pp. 163-168, 2009.

[36] J. Walrath, L. Zukowski, A. Krywiak, and R. F. Silver, "Resident Th1-like effector memory cells in pulmonary recall responses to Mycobacterium tuberculosis," American Journal of Respiratory Cell and Molecular Biology, vol. 33, no. 1, pp. 48-55, 2005.

[37] T. C. Y. Tsao, C.-C. Huang, W.-K. Chiou, P.-Y. Yang, M.-J. Hsieh, and K.-C. Tsao, "Levels of interferon- $\gamma$ and interleukin2 receptor- $\alpha$ for bronchoalveolar lavage fluid and serum were correlated with clinical grade and treatment of pulmonary tuberculosis," International Journal of Tuberculosis and Lung Disease, vol. 6, no. 8, pp. 720-727, 2002.

[38] B. Nandi and S. M. Behar, "Regulation of neutrophils by interferon- $\gamma$ limits lung inflammation during tuberculosis infection," The Journal of Experimental Medicine, vol. 208, no. 11, pp. 2251-2262, 2011.

[39] J. Chan, Y. Xing, R. S. Magliozzo, and B. R. Bloom, "Killing of virulent Mycobacterium tuberculosis by reactive nitrogen intermediates produced by activated murine macrophages," The Journal of Experimental Medicine, vol. 175, no. 4, pp. 1111-1122, 1992.

[40] H.-S. S. Choi, P. R. Rai, H. W. Chu, C. Cool, and E. D. Chan, "Analysis of nitric oxide synthase and nitrotyrosine expression in human pulmonary tuberculosis," The American Journal of Respiratory and Critical Care Medicine, vol. 166, no. 2, pp. 178186, 2002.

[41] M. G. Gutierrez, S. S. Master, S. B. Singh, G. A. Taylor, M. I. Colombo, and V. Deretic, "Autophagy is a defense mechanism inhibiting BCG and Mycobacterium tuberculosis survival in infected macrophages," Cell, vol. 119, no. 6, pp. 753-766, 2004.

[42] J. L. Flynn, M. M. Goldstein, J. Chan et al., "Tumor necrosis factor- $\alpha$ is required in the protective immune response against Mycobacterium tuberculosis in mice," Immunity, vol. 2, no. 6, pp. 561-572, 1995.

[43] A. G. D. Bean, D. R. Roach, H. Briscoe et al., "Structural deficiencies in granuloma formation in TNF gene-targeted mice 
underlie the heightened susceptibility to aerosol Mycobacterium tuberculosis infection, which is not compensated for by lymphotoxin," Journal of Immunology, vol. 162, no. 6, pp. 3504-3511, 1999.

[44] V. P. Mohan, C. A. Scanga, K. Yu et al., "Effects of tumor necrosis factor alpha on host immune response in chronic persistent tuberculosis: possible role for limiting pathology," Infection and Immunity, vol. 69, no. 3, pp. 1847-1855, 2001.

[45] M. A. Gardam, E. C. Keystone, R. Menzies et al., "Anti-tumour necrosis factor agents and tuberculosis risk: mechanisms of action and clinical management," Lancet Infectious Diseases, vol. 3, no. 3, pp. 148-155, 2003.

[46] J. Keane, "TNF-blocking agents and tuberculosis: new drugs illuminate an old topic," Rheumatology, vol. 44, no. 6, pp. 714720, 2005.

[47] X. Xie, F. Li, J.-W. Chen, and J. Wang, "Risk of tuberculosis infection in anti-TNF- $\alpha$ biological therapy: from bench to bedside," Journal of Microbiology, Immunology and Infection, vol. 47, no. 4, pp. 268-274, 2014.

[48] M. Koga, S. Terawaki, R. Tatsukawa, M. Fujita, S. Imafuku, and J. Nakayama, "Development of miliary tuberculosis related to anti-tumor necrosis factor-alpha inhibitor therapy for pustular psoriasis," The Journal of Dermatology, vol. 40, no. 6, pp. 476477, 2013.

[49] H.-M. Surcel, M. Troye-Blomberg, S. Paulie et al., “Th1/Th2 profiles in tuberculosis, based on the proliferation and cytokine response of blood lymphocytes to mycobacterial antigens," Immunology, vol. 81, no. 2, pp. 171-176, 1994.

[50] G. T. Seah, G. M. Scott, and G. A. W. Rook, “Type 2 cytokine gene activation and its relationship to extent of disease in patients with tuberculosis," Journal of Infectious Diseases, vol. 181, no. 1, pp. 385-389, 2000.

[51] R. Van Crevel, E. Karyadi, F. Preyers et al., "Increased production of interleukin 4 by $\mathrm{CD}^{+}$and $\mathrm{CD} 8^{+} \mathrm{T}$ cells from patients with tuberculosis is related to the presence of pulmonary cavities," Journal of Infectious Diseases, vol. 181, no. 3, pp. 11941197, 2000.

[52] D. Dlugovitzky, A. Torres-Morales, L. Rateni et al., "Circulating profile of Th1 and Th2 cytokines in tuberculosis patients with different degrees of pulmonary involvement," FEMS Immunology and Medical Microbiology, vol. 18, no. 3, pp. 203-207, 1997.

[53] G. Mazzarella, A. Bianco, F. Perna et al., "T lymphocyte phenotypic profile in lung segments affected by cavitary and noncavitary tuberculosis," Clinical and Experimental Immunology, vol. 132, no. 2, pp. 283-288, 2003.

[54] A. D. Howard and B. S. Zwilling, "Reactivation of tuberculosis is associated with a shift from type 1 to type 2 cytokines," Clinical and Experimental Immunology, vol. 115, no. 3, pp. 428-434, 1999.

[55] K. J. Erb, J. Kirman, B. Delahunt, W. Chen, and G. Le Gros, "IL4, IL-5 and IL-10 are not required for the control of M. bovisBCG infection in mice," Immunology and Cell Biology, vol. 76, no. 1, pp. 41-46, 1998.

[56] R. J. North, "Mice incapable of making IL-4 or IL-10 display normal resistance to infection with Mycobacterium tuberculosis," Clinical and Experimental Immunology, vol. 113, no. 1, pp. 55-58, 1998.

[57] J. Harris, S. A. De Haro, S. S. Master et al., "T helper 2 cytokines inhibit autophagic control of intracellular Mycobacterium tuberculosis," Immunity, vol. 27, no. 3, pp. 505-517, 2007.

[58] B. Jamil, F. Shahid, Z. Hasan et al., "Interferon $\gamma /$ IL10 ratio defines the disease severity in pulmonary and extra pulmonary tuberculosis," Tuberculosis, vol. 87, no. 4, pp. 279-287, 2007.
[59] Z. T. Handzel, V. Barak, Y. Altman et al., "Increased Th1 and Th2 type cytokine production in patients with active tuberculosis," Israel Medical Association Journal, vol. 9, no. 6, pp. 479-483, 2007.

[60] M. Zhang, Y. Lin, D. V. Iyer, J. Gong, J. S. Abrams, and P. F. Barnes, "T-cell cytokine responses in human infection with Mycobacterium tuberculosis," Infection and Immunity, vol. 63, no. 8, pp. 3231-3234, 1995.

[61] D. M. Higgins, J. Sanchez-Campillo, A. G. Rosas-Taraco, E. J. Lee, I. M. Orme, and M. Gonzalez-Juarrero, "Lack of IL-10 alters inflammatory and immune responses during pulmonary Mycobacterium tuberculosis infection," Tuberculosis (Edinb), vol. 89, no. 2, pp. 149-157, 2009.

[62] R. Gopal, Y. Lin, N. Obermajer et al., "IL-23-dependent IL-17 drives Th1-cell responses following Mycobacterium bovis BCG vaccination," European Journal of Immunology, vol. 42, no. 2, pp. 364-373, 2012.

[63] Z.-J. Ye, M.-L. Yuan, Q. Zhou et al., "Differentiation and recruitment of Th9 cells stimulated by pleural mesothelial cells in human Mycobacterium tuberculosis infection," PLoS ONE, vol. 7, no. 2, Article ID e31710, 2012.

[64] V. Staudt, E. Bothur, M. Klein et al., "Interferon-regulatory factor 4 is essential for the developmental program of $t$ helper 9 cells," Immunity, vol. 33, no. 2, pp. 192-202, 2010.

[65] M. S. Wilson, C. G. Feng, D. L. Barber et al., "Redundant and pathogenic roles for IL-22 in mycobacterial, protozoan, and helminth infections," Journal of Immunology, vol. 184, no. 8, pp. 4378-4390, 2010.

[66] A. A. Chackerian, J. M. Alt, T. V. Perera, C. C. Dascher, and S. M. Behar, "Dissemination of Mycobacterium tuberculosis is influenced by host factors and precedes the initiation of T-cell immunity," Infection and Immunity, vol. 70, no. 8, pp. 45014509, 2002.

[67] A. J. Wolf, B. Linas, G. J. Trevejo-Nuñez et al., "Mycobacterium tuberculosis infects dendritic cells with high frequency and impairs their function in vivo," Journal of Immunology, vol. 179, no. 4, pp. 2509-2519, 2007.

[68] A. O’Garra, P. S. Redford, F. W. McNab, C. I. Bloom, R. J. Wilkinson, and M. P. R. Berry, "The immune response in tuberculosis," Annual Review of Immunology, vol. 31, pp. 475527, 2013.

[69] A. M. Green, R. DiFazio, and J. L. Flynn, "IFN- $\gamma$ from CD4 $\mathrm{T}$ cells is essential for host survival and enhances CD8 T cell function during Mycobacterium tuberculosis infection," Journal of Immunology (Baltimore, Md. : 1950), vol. 190, no. 1, pp. 270277, 2013.

[70] S. Bhattacharyya, R. Singla, A. B. Dey, and H. K. Prasad, "Dichotomy of cytokine profiles in patients and high-risk healthy subjects exposed to tuberculosis," Infection and Immunity, vol. 67, no. 11, pp. 5597-5603, 1999.

[71] J.-S. Lee, C.-H. Song, C.-H. Kim et al., "Profiles of IFN- $\gamma$ and its regulatory cytokines (IL-12, IL-18 and IL-10) in peripheral blood mononuclear cells from patients with multidrug-resistant tuberculosis," Clinical \& Experimental Immunology, vol. 128, no. 3, pp. 516-524, 2002.

[72] R. Vankayalapati, B. Wizel, S. E. Weis et al., "Serum cytokine concentrations do not parallel Mycobacterium tuberculosisinduced cytokine production in patients with tuberculosis," Clinical Infectious Diseases, vol. 36, no. 1, pp. 24-28, 2003.

[73] C. B. Pereira, M. Palaci, O. H. M. Leite, A. J. S. Duarte, and G. Benard, "Monocyte cytokine secretion in patients with 
pulmonary tuberculosis differs from that of healthy infected subjects and correlates with clinical manifestations," Microbes and Infection, vol. 6, no. 1, pp. 25-33, 2004.

[74] E. Sahiratmadja, B. Alisjahbana, T. de Boer et al., "Dynamic changes in pro- and anti-inflammatory cytokine profiles and gamma interferon receptor signaling integrity correlate with tuberculosis disease activity and response to curative treatment," Infection and Immunity, vol. 75, no. 2, pp. 820-829, 2007.

[75] R. Al-Attiyah, A. S. Mustafa, A. T. Abal, N. M. Madi, and P. Andersen, "Restoration of mycobacterial antigen-induced proliferation and interferon- $\gamma$ responses in peripheral blood mononuclear cells of tuberculosis patients upon effective chemotherapy," FEMS Immunology \& Medical Microbiology, vol. 38, no. 3, pp. 249-256, 2003.

[76] R. Diel, R. Loddenkemper, S. Niemann, K. Meywald-Walter, and A. Nienhaus, "Negative and positive predictive value of a whole-blood interferon- $\gamma$ release assay for developing active tuberculosis: an update," The American Journal of Respiratory and Critical Care Medicine, vol. 183, no. 1, pp. 88-95, 2011.

[77] C. S. Hirsch, Z. Toossi, C. Othieno et al., "Depressed T-cell interferon $\gamma$ responses in pulmonary tuberculosis: analysis of underlying mechanisms and modulation with therapy," The Journal of Infectious Diseases, vol. 180, no. 6, pp. 2069-2073, 1999.

[78] F. Dieli, G. Friscia, C. di Sano et al., "Sequestration of T lymphocytes to body fluids in tuberculosis: reversal of anergy following chemotherapy," Journal of Infectious Diseases, vol. 180, no. 1, pp. 225-228, 1999.

[79] R. J. Wilkinson, H. M. Vordermeier, K. A. Wilkinson et al., "Peptide-specific T cell response to Mycobacterium tuberculosis: clinical spectrum, compartmentalization, and effect of chemotherapy," Journal of Infectious Diseases, vol. 178, no. 3, pp. 760-768, 1998.

[80] P. F. Barnes, S. D. Mistry, C. L. Cooper, C. Pirmez, T. H. Rea, and R. L. Modlin, "Compartmentalization of a $\mathrm{CD}^{+}{ }^{+} \mathrm{T}$ lymphocyte subpopulation in tuberculous pleuritis," Journal of Immunology, vol. 142, no. 4, pp. 1114-1119, 1989.

[81] C. Nunes-Alves, M. G. Booty, S. M. Carpenter, P. Jayaraman, A. C. Rothchild, and S. M. Behar, "In search of a new paradigm for protective immunity to TB," Nature Reviews Microbiology, vol. 12, no. 4, pp. 289-299, 2014.

[82] J. L. Flynn and J. Chan, "What's good for the host is good for the bug," Trends in Microbiology, vol. 13, no. 3, pp. 98-102, 2005.

[83] R. van Crevel, T. H. M. Ottenhoff, and J. W. M. van der Meer, "Innate immunity to Mycobacterium tuberculosis," Clinical Microbiology Reviews, vol. 15, no. 2, pp. 294-309, 2002.

[84] A. Marchant, A. Amedei, A. Azzurri et al., "Polarization of PPDspecific T-cell response of patients with tuberculosis from Th0 to Th1 profile after successful antimycobacterial therapy or in vitro conditioning with interferon-alpha or interleukin-12," The American Journal of Respiratory Cell and Molecular Biology, vol. 24, no. 2, pp. 187-194, 2001.

[85] S. B. Bradfute, E. F. Castillo, J. Arko-Mensah et al., "Autophagy as an immune effector against tuberculosis," Current Opinion in Microbiology, vol. 16, no. 3, pp. 355-365, 2013.

[86] J. Harris, S. S. Master, S. A. de Haro et al., “Th1-Th2 polarisation and autophagy in the control of intracellular mycobacteria by macrophages," Veterinary Immunology and Immunopathology, vol. 128, no. 1\&3, pp. 37-43, 2009.

[87] D. Schmid and C. Münz, "Innate and adaptive immunity through autophagy," Immunity, vol. 27, no. 1, pp. 11-21, 2007.
[88] G. A. W. Rook, R. Hernandez-Pando, K. Dheda, and G. T. Seah, "IL-4 in tuberculosis: implications for vaccine design," Trends in Immunology, vol. 25, no. 9, pp. 483-488, 2004.

[89] S. Z. Josefowicz, L.-F. Lu, and A. Y. Rudensky, "Regulatory T cells: mechanisms of differentiation and function," Annual Review of Immunology, vol. 30, pp. 531-564, 2012.

[90] R. Ribeiro-Rodrigues, T. Resende Co, R. Rojas et al., "A role for $\mathrm{CD}^{+} \mathrm{CD} 25^{+} \mathrm{T}$ cells in regulation of the immune response during human tuberculosis," Clinical \& Experimental Immunology, vol. 144, no. 1, pp. 25-34, 2006.

[91] V. Guyot-Revol, J. A. Innes, S. Hackforth, T. Hinks, and A. Lalvani, "Regulatory T cells are expanded in blood and disease sites in patients with tuberculosis," The American Journal of Respiratory and Critical Care Medicine, vol. 173, no. 7, pp. 803810, 2006.

[92] K. Ghoreschi, A. Laurence, X.-P. Yang et al., "Generation of pathogenic TH 17 cells in the absence of TGF- $\beta 2$ signalling," Nature, vol. 467, no. 7318, pp. 967-971, 2010.

[93] L. Li, S.-H. Lao, and C.-Y. Wu, "Increased frequency of $\mathrm{CD} 4^{+} \mathrm{CD} 25^{\text {high }}$ Treg cells inhibit BCG-specific induction of IFN- $\gamma$ by CD $4^{+}$T cells from TB patients," Tuberculosis, vol. 87, no. 6, pp. 526-534, 2007.

[94] X. Y. He, L. Xiao, H. B. Chen et al., "T regulatory cells and Th1/Th2 cytokines in peripheral blood from tuberculosis patients," European Journal of Clinical Microbiology and Infectious Diseases, vol. 29, no. 6, pp. 643-650, 2010.

[95] K. M. Quinn, R. S. McHugh, F. J. Rich et al., "Inactivation of $\mathrm{CD}^{+} \mathrm{CD} 25^{+}$regulatory $\mathrm{T}$ cells during early mycobacterial infection increases cytokine production but does not affect pathogen load," Immunology and Cell Biology, vol. 84, no. 5, pp. 467-474, 2006.

[96] X. P. Yang, K. Ghoreschi, S. M. Steward-Tharp et al., “Opposing regulation of the locus encoding IL-17 through direct, reciprocal actions of STAT3 and STAT5," Nature Immunology, vol. 12, no. 3, pp. 247-254, 2011.

[97] Z. Toossi, P. Gogate, H. Shiratsuchi, T. Young, and J. J. Ellner, "Enhanced production of TGF- $\beta$ by blood monocytes from patients with active tuberculosis and presence of TGF- $\beta$ in tuberculous granulomatous lung lesions," Journal of Immunology, vol. 154, no. 1, pp. 465-473, 1995.

[98] S. A. Khader, J. E. Pearl, K. Sakamoto et al., "IL-23 compensates for the absence of IL-12p70 and is essential for the IL-17 response during tuberculosis but is dispensable for protection and antigen-specific IFN- $\gamma$ responses if IL-12p70 is available," Journal of Immunology, vol. 175, no. 2, pp. 788-795, 2005.

[99] T. Lindenstrøm, J. Woodworth, J. Dietrich, C. Aagaard, P. Andersen, and E. M. Agger, "Vaccine-induced Th17 cells are maintained long-term postvaccination as a distinct and phenotypically stable memory subset," Infection and Immunity, vol. 80, no. 10, pp. 3533-3544, 2012.

[100] C. J. Murray, K. F. Ortblad, C. Guinovart et al., "Global, regional, and national incidence and mortality for HIV, tuberculosis, and malaria during 1990-2013: a systematic analysis for the Global Burden of Disease Study 2013," The Lancet, vol. 384, no. 9947, pp. 1005-1070, 2013.

[101] G. F. Sonnenberg, L. A. Fouser, and D. Artis, "Border patrol: regulation of immunity, inflammation and tissue homeostasis at barrier surfaces by IL-22," Nature Immunology, vol. 12, no. 5, pp. 383-390, 2011.

[102] M. Veldhoen, C. Uyttenhove, J. van Snick et al., "Transforming growth factor- $\beta$ 'reprograms' the differentiation of T helper 2 
cells and promotes an interleukin 9-producing subset," Nature Immunology, vol. 9, no. 12, pp. 1341-1346, 2008.

[103] Y. Yu, Y. Zhang, S. Hu et al., "Different patterns of cytokines and chemokines combined with IFN- $\gamma$ production reflect mycobacterium tuberculosis infection and disease," PLoS ONE, vol. 7, no. 9, Article ID e44944, 2012.

[104] D. Anbarasu, C. P. Raja, and A. Raja, "Multiplex analysis of cytokines/chemokines as biomarkers that differentiate healthy contacts from tuberculosis patients in high endemic settings," Cytokine, vol. 61, no. 3, pp. 747-754, 2013.

[105] Y.-G. Hur, A. C. Crampin, C. Chisambo et al., "Identification of immunological biomarkers which may differentiate latent tuberculosis from exposure to environmental nontuberculous mycobacteria in children," Clinical and Vaccine Immunology, vol. 21, no. 2, pp. 133-142, 2014.

[106] B. Wu, C. Huang, M. Kato-Maeda et al., "IL-9 is associated with an impaired Th1 immune response in patients with tuberculosis," Clinical Immunology, vol. 126, no. 2, pp. 202-210, 2008.

[107] P. C. Hill, R. H. Brookes, A. Fox et al., "Surprisingly high specificity of the PPD skin test for M. tuberculosis infection from exposure in the Gambia," PLoS ONE, vol. 1, no. 1, article e68, 2006.

[108] S. Sakaguchi, "Naturally arising $\mathrm{CD}^{+}$regulatory $\mathrm{T}$ cells for immunologic self-tolerance and negative control of immune responses," Annual Review of Immunology, vol. 22, pp. 531-562, 2004.

[109] A. T. Endharti, M. Rifa'I, Z. Shi et al., "Cutting edge: $\mathrm{CD}^{+} \mathrm{CD} 122^{+}$regulatory $\mathrm{T}$ cells produce IL-10 to suppress IFN$\gamma$ production and proliferation of $\mathrm{CD}^{+} \mathrm{T}$ cells ${ }^{1}$," Journal of Immunology, vol. 175, no. 11, pp. 7093-7097, 2005.

[110] A. O'Garra and P. Vieira, “TH1 cells control themselves by producing interleukin-10," Nature Reviews Immunology, vol. 7, no. 6 , pp. 425-428, 2007.

[111] J. Zhu, H. Yamane, and W. E. Paul, "Differentiation of effector CD4 T cell populations*", Annual Review of Immunology, vol. 28, pp. 445-489, 2010.

[112] M. J. McGeachy, K. S. Bak-Jensen, Y. Chen et al., "TGF- $\beta$ and IL6 drive the production of IL-17 and IL-10 by T cells and restrain TH-17 cell-mediated pathology," Nature Immunology, vol. 8, no. 12, pp. 1390-1397, 2007.

[113] V. Dardalhon, A. Awasthi, H. Kwon et al., "IL-4 inhibits TGF$\beta$-induced Foxp $3^{+}$T cells and, together with TGF- $\beta$, generates IL- $9^{+}$IL-10 ${ }^{+}$Foxp $3^{-}$effector T cells," Nature Immunology, vol. 9, no. 12, pp. 1347-1355, 2008.

[114] C. I. Kingsley, M. Karim, A. R. Bushell, and K. J. Wood, "CD $25^{+} \mathrm{CD} 4^{+}$regulatory T cells prevent graft rejection: CTLA4- and IL-10-dependent immunoregulation of alloresponses," Journal of Immunology, vol. 168, no. 3, pp. 1080-1086, 2002.

[115] M. Miyara and S. Sakaguchi, "Natural regulatory T cells: mechanisms of suppression," Trends in Molecular Medicine, vol. 13, no. 3, pp. 108-116, 2007.

[116] R. Bacchetta, M. Bigler, J.-L. Touraine et al., "High levels of interleukin 10 production in vivo are associated with tolerance in SCID patients transplanted with HLA mismatched hematopoietic stem cells," Journal of Experimental Medicine, vol. 179, no. 2, pp. 493-502, 1994.

[117] H. Groux, A. O'Garra, M. Bigler et al., "A CD4 ${ }^{+}$T-cell subset inhibits antigen-specific T-cell responses and prevents colitis," Nature, vol. 389, no. 6652, pp. 737-742, 1997.
[118] M. G. Roncarolo, R. Bacchetta, C. Bordignon, S. Narula, and M. K. Levings, “Type $1 \mathrm{~T}$ regulatory cells," Immunological Reviews, vol. 182, pp. 68-79, 2001.

[119] F. Gerosa, C. Paganin, D. Peritt et al., "Interleukin-12 primes human CD4 and CD8 $\mathrm{T}$ cell clones for high production of both interferon- $\gamma$ and interleukin-10," Journal of Experimental Medicine, vol. 183, no. 6, pp. 2559-2569, 1996.

[120] L. R. Castellano, D. C. Filho, L. Argiro et al., “Th1/Th2 immune responses are associated with active cutaneous leishmaniasis and clinical cure is associated with strong interferon- $\gamma$ production," Human Immunology, vol. 70, no. 6, pp. 383-390, 2009.

[121] D. Jankovic, M. C. Kullberg, C. G. Feng et al., "Conventional T-bet ${ }^{+}$Foxp $3^{-}$Th1 cells are the major source of host-protective regulatory IL-10 during intracellular protozoan infection," Journal of Experimental Medicine, vol. 204, no. 2, pp. 273-283, 2007.

[122] M. Daheshia, N. Kuklin, S. Kanangat, E. Manickan, and B. T. Rouse, "Suppression of ongoing ocular inflammatory disease by topical administration of plasmid DNA encoding IL-10," The Journal of Immunology, vol. 159, no. 4, pp. 1945-1952, 1997.

[123] D. R. Nelson, G. Y. Lauwers, J. Y. N. Lau, and G. L. Davis, "Interleukin 10 treatment reduces fibrosis in patients with chronic hepatitis C: a pilot trial of interferon nonresponders," Gastroenterology, vol. 118, no. 4, pp. 655-660, 2000.

[124] S. Mocellin, F. Marincola, C. R. Rossi, D. Nitti, and M. Lise, "The multifaceted relationship between IL-10 and adaptive immunity: putting together the pieces of a puzzle," Cytokine and Growth Factor Reviews, vol. 15, no. 1, pp. 61-76, 2004.

[125] C. A. Hunter, L. A. Ellis-Neyes, T. Slifer et al., "IL-10 is required to prevent immune hyperactivity during infection with Trypanosoma cruzi," The Journal of Immunology, vol. 158, no. 7, pp. 3311-3316, 1997.

[126] M. Deckert, S. Soltek, G. Geginat et al., "Endogenous interleukin-10 is required for prevention of a hyperinflammatory intracerebral immune response in Listeria monocytogenes meningoencephalitis," Infection and Immunity, vol. 69, no. 7, pp. 4561-4571, 2001.

[127] J. Sun, R. Madan, C. L. Karp, and T. J. Braciale, "Effector T cells control lung inflammation during acute influenza virus infection by producing IL-10," Nature Medicine, vol. 15, no. 3, pp. 277-284, 2009.

[128] R. T. Gazzinelli, M. Wysocka, S. Hieny et al., "In the absence of endogenous IL-10, mice acutely infected with Toxoplasma gondii succumb to a lethal immune response dependent on $\mathrm{CD}^{+} \mathrm{T}$ cells and accompanied by overproduction of IL-12, IFN- $\gamma$, and TNF- $\alpha$," The Journal of Immunology, vol. 157, no. 2 , pp. 798-805, 1996.

[129] Y. Suzuki, A. Sher, G. Yap et al., "IL-10 is required for prevention of necrosis in the small intestine and mortality in both genetically resistant $\mathrm{BALB} / \mathrm{c}$ and susceptible C57BL/6 mice following peroral infection with Toxoplasma gondii," Journal of Immunology, vol. 164, no. 10, pp. 5375-5382, 2000.

[130] Y. Belkaid, C. A. Piccirillo, S. Mendez, E. M. Shevach, and D. L. Sacks, "CD $4{ }^{+} \mathrm{CD} 25^{+}$regulatory $\mathrm{T}$ cells control Leishmania major persistence and immunity," Nature, vol. 420, no. 6915, pp. 502-507, 2002.

[131] P. J. Murray, L. Wang, C. Onufryk, R. I. Tepper, and R. A. Young, "T cell-derived IL-10 antagonizes macrophage function in mycobacterial infection," Journal of Immunology, vol. 158, no. 1, pp. 315-321, 1997.

[132] J. F. D. Siawaya, N. Beyers, P. van Helden, and G. Walzl, "Differential cytokine secretion and early treatment response in 
patients with pulmonary tuberculosis," Clinical \& Experimental Immunology, vol. 156, no. 1, pp. 69-77, 2009.

[133] F. Gerosa, C. Nisii, S. Righetti et al., " $\mathrm{CD} 4^{+} \mathrm{T}$ cell clones producing both interferon- $\gamma$ and interleukin-10 predominate in bronchoalveolar lavages of active pulmonary tuberculosis patients," Clinical Immunology, vol. 92, no. 3, pp. 224-234, 1999.

[134] K. W. Moore, R. de Waal Malefyt, R. L. Coffman, and A. O'Garra, "Interleukin-10 and the interleukin-10 receptor," Annual Review of Immunology, vol. 19, pp. 683-765, 2001.

[135] S. Stäger, A. Maroof, S. Zubairi, S. L. Sanos, M. Kopf, and P. M. Kaye, "Distinct roles for IL-6 and IL-12p40 in mediating protection against Leishmania donovani and the expansion of IL-10 ${ }^{+} \mathrm{CD}^{+}{ }^{+} \mathrm{T}$ cells," European Journal of Immunology, vol. 36, no. 7, pp. 1764-1771, 2006.

[136] C. F. Anderson, M. Oukka, V. J. Kuchroo, and D. Sacks, "CD4 ${ }^{+} \mathrm{CD} 25^{-}$Foxp3 ${ }^{-}$Th1 cells are the source of IL-10-mediated immune suppression in chronic cutaneous leishmaniasis," Journal of Experimental Medicine, vol. 204, no. 2, pp. 285-297, 2007.

[137] A. P. F. do Rosário, T. Lamb, P. Spence et al., "IL-27 promotes IL10 production by effector Th1 $\mathrm{CD} 4^{+} \mathrm{T}$ cells: a critical mechanism for protection from severe immunopathology during malaria infection," The Journal of Immunology, vol. 188, no. 3, pp. 11781190, 2012.

[138] D. F. Fiorentino, M. W. Bond, and T. R. Mosmann, "Two types of mouse T helper cell. IV. Th2 clones secrete a factor that inhibits cytokine production by Th1 clones," The Journal of Experimental Medicine, vol. 170, no. 6, pp. 2081-20095, 1989.

[139] S.-H. Im, A. Hueber, S. Monticelli, K.-H. Kang, and A. Rao, "Chromatin-level regulation of the IL10 gene in T cells," The Journal of Biological Chemistry, vol. 279, no. 45, pp. 4681846825, 2004.

[140] H. D. Chang, C. Helbig, L. Tykocinski et al., "Expression of IL10 in Th memory lymphocytes is conditional on IL-12 or IL4, unless the IL-10 gene is imprinted by GATA-3," European Journal of Immunology, vol. 37, no. 3, pp. 807-817, 2007.

[141] M. Assenmacher, J. Schmitz, and A. Radbruch, "Flow cytometric determination of cytokines in activated murine $\mathrm{T}$ helper lymphocytes: expression of interleukin-10 in interferon- $\gamma$ and in interleukin-4-expressing cells," European Journal of Immunology, vol. 24, no. 5, pp. 1097-1101, 1994.

[142] G. Del Prete, M. De Carli, F. Almerigogna, M. G. Giudizi, R. Biagiotti, and S. Romagnani, "Human IL-10 is produced by both type 1 helper (Th1) and type 2 helper (Th2) T cell clones and inhibits their antigen-specific proliferation and cytokine production," Journal of Immunology, vol. 150, no. 2, pp. 353-360, 1993.

[143] A. Roers, L. Siewe, E. Strittmatter et al., "T cell-specific inactivation of the interleukin 10 gene in mice results in enhanced $\mathrm{T}$ cell responses but normal innate responses to lipopolysaccharide or skin irritation," The Journal of Experimental Medicine, vol. 200, no. 10, pp. 1289-1297, 2004.

[144] B. Sawitzki, C. I. Kingsley, V. Oliveira, M. Karim, M. Herber, and K. J. Wood, "IFN- $\gamma$ production by alloantigen-reactive regulatory $\mathrm{T}$ cells is important for their regulatory function in vivo," Journal of Experimental Medicine, vol. 201, no. 12, pp. 1925-1935, 2005.

[145] D. Jankovic, D. G. Kugler, and A. Sher, "IL-10 production by CD4+ effector T cells: a mechanism for self-regulation," Mucosal Immunology, vol. 3, no. 3, pp. 239-246, 2010.

[146] C. Pot, H. Jin, A. Awasthi et al., "Cutting edge: IL-27 induces the transcription factor c-Maf, cytokine IL-21, and the costimulatory receptor ICOS that coordinately act together to promote differentiation of IL-10-producing Trl cells," The Journal of Immunology, vol. 183, no. 2, pp. 797-801, 2009.

[147] R. Rodrigues Dos Santos Jr., A. Sartori, V. L. Deperon Bonato et al., "Immune modulation induced by tuberculosis DNA vaccine protects non-obese diabetic mice from diabetes progression," Clinical and Experimental Immunology, vol. 149, no. 3, pp. 570578, 2007.

[148] D. Elias, H. Prigozin, N. Polak, M. Rapoport, A. W. Lohse, and I. R. Cohen, "Autoimmune diabetes induced by the $\beta$-cell toxin STZ: immunity to the $60-\mathrm{kDa}$ heat shock protein and to insulin," Diabetes, vol. 43, no. 8, pp. 992-998, 1994.

[149] A. Zanin-Zhorov, L. Cahalon, G. Tal, R. Margalit, O. Lider, and I. R. Cohen, "Heat shock protein 60 enhances $\mathrm{CD} 4{ }^{+} \mathrm{CD} 25^{+}$ regulatory T cell function via innate TLR2 signaling," Journal of Clinical Investigation, vol. 116, no. 7, pp. 2022-2032, 2006.

[150] M. Saraiva, J. R. Christensen, M. Veldhoen, T. L. Murphy, K. M. Murphy, and A. O'Garra, "Interleukin-10 production by Th1 cells requires interleukin-12-induced STAT4 transcription factor and ERK MAP kinase activation by high antigen dose," Immunity, vol. 31, no. 2, pp. 209-219, 2009.

[151] M. H. Shaw, G. J. Freeman, M. F. Scott et al., "Tyk2 negatively regulates adaptive Th1 immunity by mediating IL-10 signaling and promoting IFN-gamma-dependent IL-10 reactivation," Journal of Immunology, vol. 176, no. 12, pp. 7263-7271, 2006.

[152] R. Spolski and W. J. Leonard, "Interleukin-21: basic biology and implications for cancer and autoimmunity," Annual Review of Immunology, vol. 26, pp. 57-79, 2008.

[153] R. Spolski, H.-P. Kim, W. Zhu, D. E. Levy, and W. J. Leonard, "IL-21 mediates suppressive effects via its induction of IL-10," Journal of Immunology, vol. 182, no. 5, pp. 2859-2867, 2009.

[154] W. Cui, Y. Liu, J. S. Weinstein, J. Craft, and S. M. Kaech, "An interleukin-21- interleukin-10-STAT3 pathway is critical for functional maturation of memory $\mathrm{CD}^{+} \mathrm{T}$ cells," Immunity, vol. 35, no. 5, pp. 792-805, 2011.

[155] J. A. Olson and S. C. Jameson, "Keeping STATs on memory CD8 ${ }^{+}$T cells," Immunity, vol. 35, no. 5, pp. 663-665, 2011.

[156] K. E. Foulds, M. J. Rotte, and R. A. Seder, "IL-10 is required for optimal CD8 T cell memory following Listeria monocytogenes infection," Journal of Immunology, vol. 177, no. 4, pp. 2565-2574, 2006.

[157] J. C. Cyktor, B. Carruthers, G. L. Beamer, and J. Turner, “Clonal expansions of CD8+ T cells with IL-10 secreting capacity occur during chronic Mycobacterium tuberculosis infection," PLoS ONE, vol. 8, no. 3, Article ID e58612, 2013.

[158] D. Sauma, P. Espejo, A. Ramirez, A. Fierro, M. Rosemblatt, and M. R. Bono, "Differential regulation of Notch ligands in dendritic cells upon interaction with T helper cells," Scandinavian Journal of Immunology, vol. 74, no. 1, pp. 62-70, 2011.

[159] S. Rutz, M. Janke, N. Kassner, T. Hohnstein, M. Krueger, and A. Scheffold, "Notch regulates IL-10 production by T helper 1 cells," Proceedings of the National Academy of Sciences of the United States of America, vol. 105, no. 9, pp. 3497-3502, 2008.

[160] F. Auderset, M. Coutaz, and F. Tacchini-Cottier, "The role of notch in the differentiation of $\mathrm{CD}^{+}{ }^{+} \mathrm{T}$ helper cells," Current Topics in Microbiology and Immunology, vol. 360, pp. 115-134, 2012.

[161] C. Helbig, R. Gentek, R. A. Backer et al., "Notch controls the magnitude of $\mathrm{T}$ helper cell responses by promoting cellular longevity," Proceedings of the National Academy of Sciences of the United States of America, vol. 109, no. 23, pp. 9041-9046, 2012. 
[162] L. Rivino, P. Gruarin, B. Häringer et al., "CCR6 is expressed on an IL-10-producing, autoreactive memory $\mathrm{T}$ cell population with context-dependent regulatory function," Journal of Experimental Medicine, vol. 207, no. 3, pp. 565-577, 2010.

[163] S. Alas, C. Emmanouilides, and B. Bonavida, "Inhibition of interleukin 10 by Rituximab results in down-regulation of Bcl-2 and sensitization of B-cell non-Hodgkin's lymphoma to apoptosis," Clinical Cancer Research, vol. 7, no. 3, pp. 709-723, 2001.

[164] Z. S. Boyd, A. Kriatchko, J. Yang, N. Agarwal, M. B. Wax, and R. V. Patil, "Interleukin-10 receptor signaling through STAT-3 regulates the apoptosis of retinal ganglion cells in response to stress," Investigative Ophthalmology \& Visual Science, vol. 44, no. 12, pp. 5206-5211, 2003.

[165] S. Sieg, C. King, Y. Huang, and D. Kaplan, "The role of interleukin-10 in the inhibition of T-cell proliferation and apoptosis mediated by parainfluenza virus type 3," Journal of Virology, vol. 70, no. 7, pp. 4845-4848, 1996.

[166] K. Taga, J. Chretien, B. Cherney, L. Diaz, M. Brown, and G. Tosato, "Interleukin-10 inhibits apoptotic cell death in infectious mononucleosis T cells," Journal of Clinical Investigation, vol. 94, no. 1, pp. 251-260, 1994.

[167] S. Poitevin, S. B. H. K. Kechiche, C. Macé, and P. Nguyen, "IL-10 inhibits apoptosis and microvesiculation of human monocytes," Journal of Thrombosis and Haemostasis, vol. 7, no. 7, pp. 12411243, 2009.

[168] H. Yang and S.-C. Chen, "The effect of interleukin-10 on apoptosis in macrophages stimulated by oxLDL," European Journal of Pharmacology, vol. 657, no. 1-3, pp. 126-130, 2011.

[169] S. Dhingra, A. K. Bagchi, A. L. Ludke, A. K. Sharma, and P. K. Singal, "Akt regulates IL-10 mediated suppression of TNF $\alpha$-induced cardiomyocyte apoptosis by upregulating stat 3 phosphorylation," PLoS ONE, vol. 6, no. 9, Article ID e25009, 2011.

[170] J. J. Donnelly, J. B. Ulmer, J. W. Shiver, and M. A. Liu, "DNA vaccines," Annual Review of Immunology, vol. 15, pp. 617-648, 1997.

[171] J. J. Donnelly, B. Wahren, and M. A. Liu, "DNA vaccines: progress and challenges," The Journal of Immunology, vol. 175, no. 2, pp. 633-639, 2005.

[172] V. L. D. Bonato, V. M. F. Lima, R. E. Tascon, D. B. Lowrie, and C. L. Silva, "Identification and characterization of protective T cells in hsp65 DNA- vaccinated and Mycobacterium tuberculosisinfected mice," Infection and Immunity, vol. 66, no. 1, pp. 169175, 1998.

[173] V. L. D. Bonato, E. D. C. Gonçalves, E. G. Soares et al., "Immune regulatory effect of pHSP65 DNA therapy in pulmonary tuberculosis: activation of $\mathrm{CD}^{+}$cells, interferon- $\gamma$ recovery and reduction of lung injury," Immunology, vol. 113, no. 1, pp. 130138,2004

[174] D. B. Lowrie, R. E. Tascon, V. L. D. Bonato et al., “Therapy of tuberculosis in mice by DNA vaccination," Nature, vol. 400, no. 6741, pp. 269-271, 1999.

[175] C. L. Silva, V. L. D. Bonato, V. M. F. Lima, L. H. Faccioli, and S. C. Leão, "Characterization of the memory/activated T cells that mediate the long-lived host response against tuberculosis after bacillus Calmette-Guérin or DNA vaccination," Immunology, vol. 97, no. 4, pp. 573-581, 1999.

[176] W. van Eden, R. van der Zee, and B. Prakken, "Heat-shock proteins induce T-cell regulation of chronic inflammation," Nature Reviews Immunology, vol. 5, no. 4, pp. 318-330, 2005.
[177] R. R. Santos Junior, A. Sartori, D. S. Lima et al., "DNA vaccine containing the mycobacterial hsp65 gene prevented insulitis in MLD-STZ diabetes," Journal of Immune Based Therapies and Vaccines, vol. 7, article 4, 2009.

[178] S. F. Zorzella-Pezavento, C. P. Guerino, F. Chiuso-Minicucci et al., "BCG and BCG/DNAhsp65 vaccinations promote protective effects without deleterious consequences for experimental autoimmune encephalomyelitis," Clinical and Developmental Immunology, vol. 2013, Article ID 721383, 9 pages, 2013. 


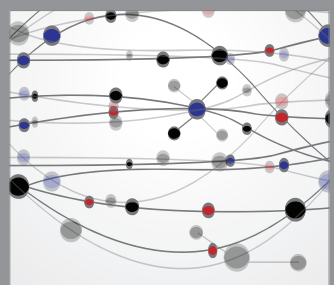

The Scientific World Journal
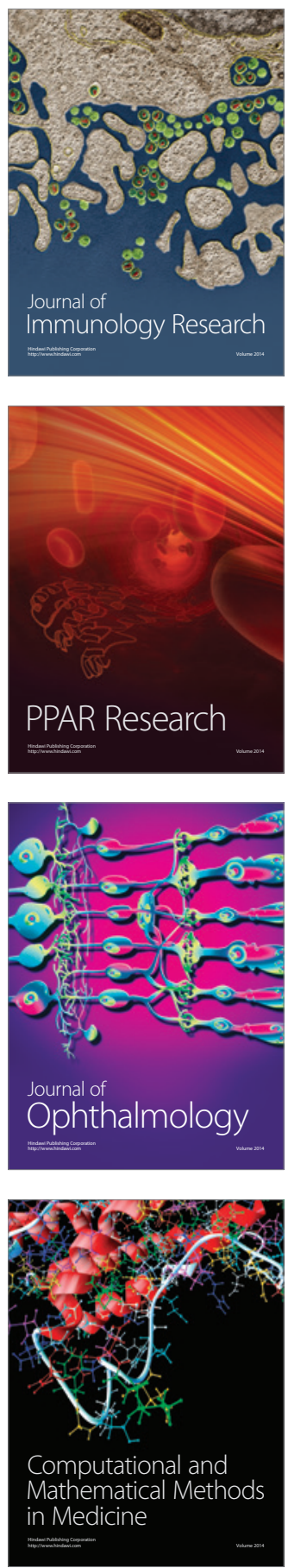

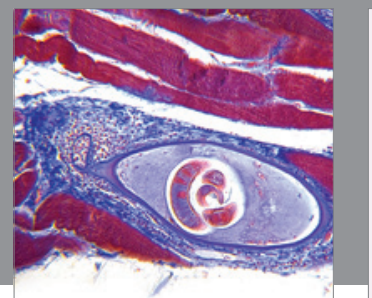

Gastroenterology

Research and Practice
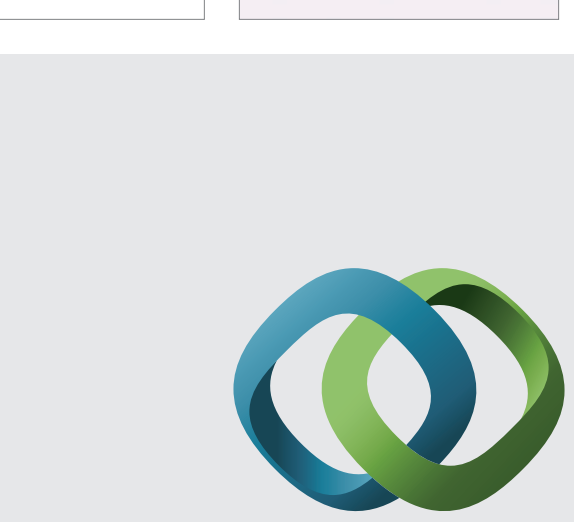

\section{Hindawi}

Submit your manuscripts at

http://www.hindawi.com
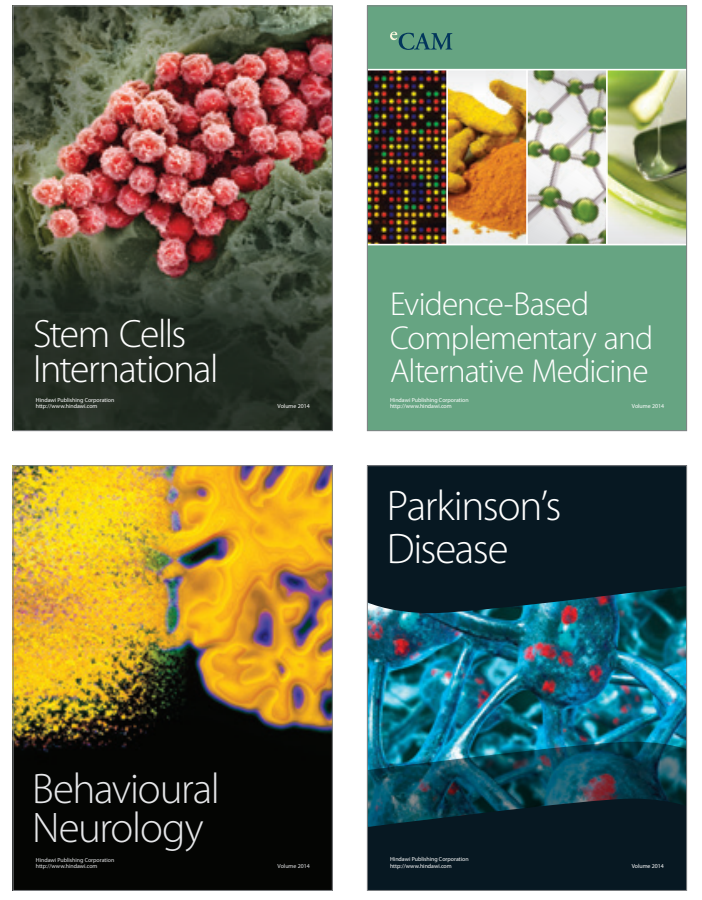
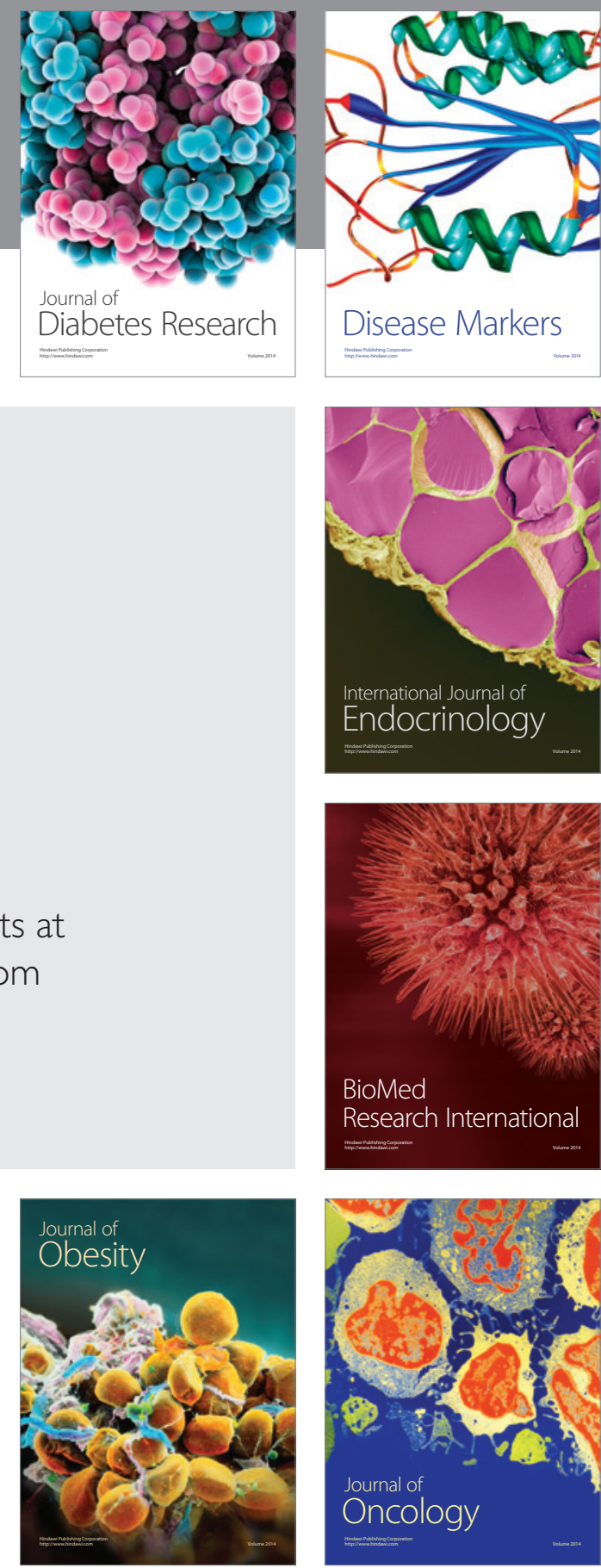

Disease Markers
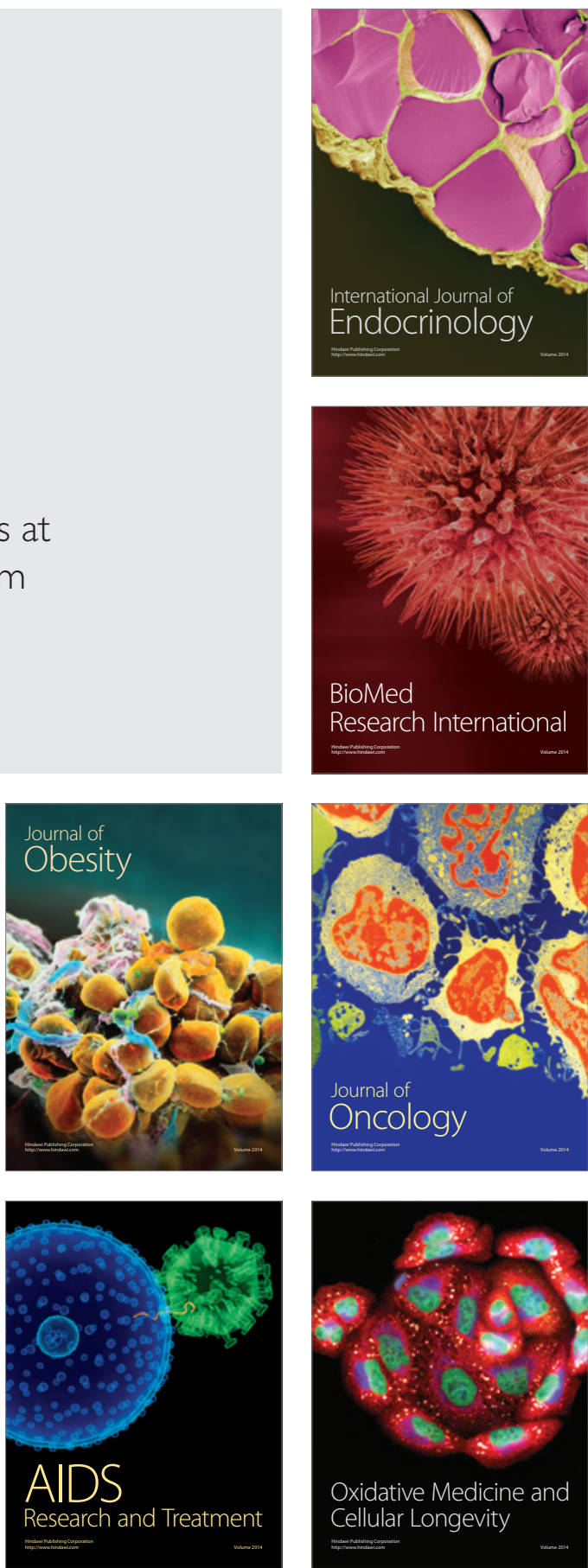